バイバスを行なったもの 3 例，陳旧性晨胸の 1 例を対象 とした. 結果，1）C.I. は術直前直後に低下したが州 室後より術前値に復した，2）PAP，PWP，CVPは術 後第 2 日ないし第 3 日に最高値となり以後下降した．3） $\mathrm{A}-\mathrm{aDO}_{2}$ は術後增大し以後しだいに回復したが第5 病日 でも術前値に比し増大傾向を示した４）肺切群では非 肺切群より A-aDO2 の回復仕良好であった．5）高龄 者では C.I. の回復が達れ PAP, PWP の上界が著しか った．6）心電图異常を認めたものは $\mathrm{A}-\mathrm{aDO}_{2}$ の回復 が遅く，PAP，PWP の上昇が著しかった。

II-D-50. 開腹術後の肺合併症発生因子の臨床的検討 東京大学第 3 外科

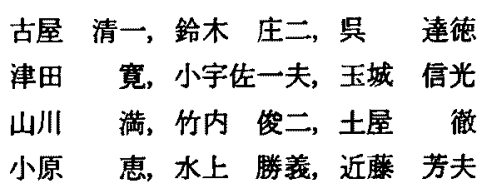

対象・方法：昭和47年か 5 54年の 教室入院胃癌患者 557例中， $R_{2}$ 以上の胃亚全摘治㗪切除例309例について, 得後肺病变発生率と臨床的因子との関係を検討した。肺 病変の有無は術後 1 遇間までのX線フイルムによって判 定した.

成䒈：肺病变発生率は50年までの前半 4 年間 $6.0 \%$ ， 51 年以後の後半 4 年間 $1.9 \%$ で有意差 $(p<0.05)$ を認め た.しかし，この期間の䠦床的因子（年柃，手術時間， 術中出血量, 同輸血量, 同輸液量, 時間輸液量, 血清蛋 白, アルブミン, $\mathrm{A} / \mathrm{G}, \mathrm{Na}, \mathrm{K}$, 全血 $\mathrm{Hb}$ 漕度, \%体重), 術挠血液ガス $\left(\mathrm{PaCO}_{2}, \mathrm{PaO}_{2}\right)$ 变動には，経年的変化は 認められなかった。

結論：上記の臨床的因子によって, 術後肺病变発生率 低下を説明することは不可能と考えられるが，昭和50年 末より行なわれた無菌的麻醉手技の励行か，好欺隌を与 えたるのと考えられる。

坐長のまとめ 古展 清一

㭪後の心肺機能の変化と，その合併症は，生命に直接 的な危険を持っているため，䠘床医の関心は大きい，本 セッションの演題は, 直接的, 間接的にこれらの問題を とり上げたものである. 討論は以上のよらに，具体的，
臨床的なむのが多かった．それらの成因や予防法，治療 法を明らかにするためには，正確なデータの積み上げと 優れた考察を必要とするか，討論を通して今後進むべき 正しい方向か沶唆されたるのと思われる.

[II－D-44] Carlens tube と異なってッバがないた め，気管内での位眉の决定に不安が表明されたが（東海 大外科，山崎氏），㨉管時刀手ごたえとその後の聴診に よって比較的容易に位置を決めることができるとのこと である。な捛国産品がないたかの不自由さる指摘された [II-D-45]出血による閉塞に対する不安が述べられ た(東京遁信病院外科, 山崎氏).これに対して演者は 閉胸時に充分止血をすること，或いは生理食塩水を胸整 内に入れて閉胸することなどの方法によって，血液によ る管の閉塞は予防可能であるが，充分に注意をする必要 があると答えた。［II－D-46] 術後みられる不整脈の 治療指針は内科的なむのと全く同一でよいといらことで ある・なおスワンガンッカテーテルの挿入と留置につい ては (福岡大 2 外, 白日氏), 約 $2 / 1$ 症例に挿入され, 最大 5 日間留置したとのことであった。〔IIーDー47] 胸部レ線所見に関する質問（大垣市民病院，笹谷氏） に対して, アテレクターゼや胸水詝留はあったか，文献 にみられるような肺䐬资の経験はなかったとのことであ る.続いて, 勝炎の病型と肺病変との関係, 治療として PEEP，CPPB，利尿㓮の投与が有效であったといら释 験が報告された（金沢大 2 外，藤田氏). 演者の症例の らち手術をしたものは出血性膵次であったという、〔【I ーDー48] 殆ど討議は行われなかったが，衍後のジギタ リス使用に関して出血量たけををと基準にすることにつ いて坐長から铰問が提出された。〔IIーD -49〕肺循票 に関与する因子としては，血夜量以外のるのる大きいと 思われるので, この点について更に研究を進めることが 望ましいと思われる。〔II-D-50] 訹前の気管支炎， 乫煙, 肺機能との関係 (福岡第 2 外, 白日氏), 胸水詝 留と腹水との関係（東海大 2 外，山畸氏）について, 瞋 機能の5ち気流速度の低下は肺合垪症の発生と関俰する こと, 腹肤内の炎症性合併症は，胸水眝留を明らかに促 進することなどを中心に討論が行なわれた.

\title{
$\mathbf{E}$ 会 場 午前の部
}

門脈 I (E-1～7) 座長 小林 廸夫

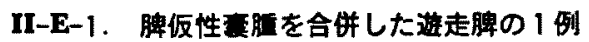
愛媛大学第 1 外科 後藤 登, 勝吕徹
暒原伸介，佰川訸吾 日本に打ける埵裏腫の報告は近年では，第33回の本会 にて鉿木らが78例，その後三浦らが110例の報告を行っ 
ているか，それらの中に遊走脾に合併したものはみられ ない，欧米においてむ，わずかに Blank らかi，遊走脾 に epidermoid cyst を合併した症例を一例報告している のにとどまる.

我々は18葴の妊娠初期の女性に遊走脾に2 次性脾斑腫 を合併した症例を得たので報告する. Robbins らの二 例の例外的報告はあるるのの本症例でる他の腹腔内䑏器 に英腫は認められなかった。 Woodward のいらよらに lienorenal ligament は形成されておらず膵尾部は約 $4 \mathrm{~cm}$ にわたって後腹壁に固定されておらず可動性がみられ た. 摘出脾は700g あり $400 \mathrm{~g}$ に及ら゙単房性意腫の内容は, コレステリン結晶を含むチョコレート色の液体であっ た. 亯腫は脾の下極にあり直径 $11 \mathrm{~cm}$ のほぼ球形をなし、 内面梳 Blank, Robbins Pirinek $5 の$ epidermoid cyst 之同様，心贜の肉柱を思わせるむのであった。組織標本で は，脾実質はなんら異常なく墓腫の内腔面に上皮構造は みられず結合樴で椣成され，Martin の分類による Secondary cyst であった.

II-E-2. 胆石を合併した茺伝性球状赤血球症の胆 菕・脾墒の1例

$$
\begin{aligned}
& \text { 東京女子医大消化器病センター外科 } \\
& \text { 田中 精一, 小川 健治, 三浦 修 } \\
& \text { 今西 定一, 增山 克, 安田 秀喜 } \\
& \text { 金山和子, 村上平, 今泉 俊秀 } \\
& \text { 荻野 和已，鈴木 重弘，井手博子 } \\
& \text { 鈴木 茂、㮃原宣 }
\end{aligned}
$$

遗云性球状赤血球症は，客血性筫血，黄疸，脾尰を主 な效候とし，常染色体佰性遗云を示す血液疾患で，摘脾 㭪により症状の著明な改善をみる事，また高率に胆石症 を合併する事で，我々外科の分野でむ興味がすたれる。

今回は，胆石症を合併した同一家系内の70歳女性とそ の啋の17藏男性の 2 人の球状赤血球症の患者に，胆要摘 出・脾摘出術を加え，臨床症状と血液検査值に著明な改 善がみられ，さらに家系調査により遗伝性である事が判 明したので，症例を呈示して同家系を稆介した。

尚，診断には，1）末梢血内に球状赤血球の存在する 事，2）赤血球渗透正脆弱性の亢進，3）溶血の元進， 4）クームス陚検陰性，5）家系内に同様の疾患を認め る事が必要とされる。

II-E-3. 胆石を伴った遗伝性球状赤血球应の2 治医 bi

国立浜田病院外科

岩永 幸夫, 武田 弘，賀戸 和男
日吉 克己, 岡野一広, 河田 知辟

西川胃腸内科医院 西川 㓐彦

遗伝性球状赤血球症は，遗云性血痹疾患の中では比較 的良く知られた疾患であり，又胆石庭を合併する頻度も 高いと云われている。

我々は最近胆石を伴った遗云性球状赤血球症を 2 例経 倹し，治缶せしめたので報告する．症例 1 は，既に報告 したが62歳の女性，胆石症を指摘されて入院，精查の結 果，著明な貧血と黄疸及び脾腫等を認め，又胆美造影で 結石像す確認，胆石を伴った遗质性球状赤血球应の診断 の下に，摘脾術及び胆美剔出術を施行. 脾腫は510g 胆 蕉結石は 6 コのビリルビン系結石であった．症例 2 は63 葴の女性, 同様に高度の筫血, 黄疸及び脾腫等を認めた が，胆石は確認できなかった。

開腹術を施行したところ530g の脾連と共に 3 コのビ リルビン系の胆咅結石を認めた。両应例とす術後経過は 順調で，諸症状の著明な改善を認め，現在る異常は認め ていない.

\section{II-E-4. 当科における脾摘例の検討} 岩手県立中央病院第 2 外科

$$
\begin{aligned}
& \text { 高橋正二郎, 高松 } \text { 正之 } \\
& \text { 小川 将, 伊藤 媇 }
\end{aligned}
$$

当科において過去10年間に脾摘を行った例は胃癌，噴 門癌等の漈の合併脾摘を除き12例である。

遗伀性球状赤血球症 4 例と自己免疫性溶血性筫血 1 例 について見ると前者の中 3 例は父姉妹の家族内発生で父 親は胆石をむ合併していた．脾は288g か.5770g と比較 的大きく又 2 例に手術時数二の副脾を認め合併摘出を行 った。術後の踢床症状は著明に改着されとくに前者は脾 摘の絶対適応と言える。

特発性血小板減少性紫珓病は3 例で中 1 例は妊娠中毒 により帝王切開で分婏しその際摘脾を併せ行なった。こ

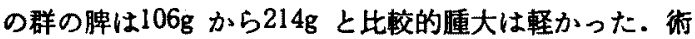
後程過は良好で血小板增加之出血傾向の改善を見た。し かし作ら術後 7 乃至10日目に逆に血小板が50万又は60万 と過增する場合があり一過性の凝固能異常亢進に留意せ ねばならない。

外侮により脾摘を余儀なくされた例は 2 例で何れる重 度複硁外傷で繁急手術と大量の輸血を要した，2歳男子 の例は腹腔内に可成りの出血を見たにも拘らず開腹時に は睥は数コの断片となって自然止血しており，血管結禁 は全く不要であった，通常損傷時止血困難な脾にこのよ らな自然止血を見た事は如何なる機序によるるのか興味 
深い。

特殊の例としては巨脾, 䝯血, 関節痛等を主改とする フェルティ症候群があり脾は1,050g と巨大であった。 術後症状改善を見たが皮局の色素沈着は不变であった。

最近脾摘の適応が唱えられて来ている慢性骨噵性白血 病に対し 1 例脾摘を行った。術後の経過にその意義を認 められはしたがなお今後の検討と症例を重ねるべき必要 のある分野である事を痛感した。

II-E-5. 脾出血に対する $\mathrm{CO}_{2}$ レーザーの止血奻果 筑波大学臨床医学系外科

高瀬 靖広, 折居 和雄, 名越 和夫 健, 更科広実, 竹島徹 深尾立, 尾崎 梓, 岡村 隆夫 岩崎 洋治

抄録号参照

II-E-6. 門え症に対する術前後の PTP の経政 成田赤十字病院外科

佐藤 英樹, 市村 公道, 山中 羲秀 小久保茂樹, 田沢 敏夫, 渡辺 進

千葉大第 1 内科 高安 賢一

昨年10月より，1年間に経皮経肝的門脈造影（以下 PTP) を細い穿刺針による千葉大内科方式に従い，10症 例に12回施行した。疾患別では，肝硬变 5 例，バンチ病 1 例，僈性肝炎 1 例，胃癌 2 例，膵頭部癌 1 例である. 今回は, 門脈圧亢進症の直達手術の前後に PTP を施行 した症例を検討した。症例 1 は39歳男性で，20年前より 日本酒を $5 \sim 8$ 合常领. 2 力月前よりタール便が持続. 当院内科を受診し，肝硬変と食道静脈瘤と診断され当科 一転科。手術は左開胸し, 食道下部にて食道離断術, 経 横隔膜的胃上部血行郭清, 摘脾を一期的に行った。術後 1 力月で肝性腷症を発症し, ラクチェロースの投与等に より症状は消失した。術前の PTPでは, 門脈圧は $42 \mathrm{~cm}$ $\mathrm{H}_{2} \mathrm{O}$ で，上腸間膜静脈の血流は，大半が $12 \mathrm{~mm}$ と抎張 した左胃静脈入逆流し食道粘膜下静脈叢へと造影され た。また，自然発生的脾叒短絡路も見られた。術後の PTP では上腸間膜静脈の血流は，大半は脾静脈より脾 腎短絡路へ流九た。脾静脈の幅は術前か９ $9 \mathrm{~mm}$ に比し術 後は13mm と太くなり，門脈采より下大静脈への急放 な血流の增加が術後の肝性脳庭を発症させたものと考息 た. 症例 2 は 42 歳女性で 7 年前アルコール性汗硬変と食 道静脈瘤破裂で倉道離断術と摘脾を施行. 1 年前再吐血 し，食道静脈瘤の再発之祅断され，近医で20日間入院. 手術のため当科入院し，食道離断術と胃下部血行郭清を
経胸的に行った。術前のPTP では，上腸間膜静脈の血 流は，胃冠状静脈一逆流が見られたが，衍後1カ月で は，胃冠状觧脈への血流の逆流は全く見られなかった。 結語 : 門脈圧六進症の 直達手術施行例に, 術前後の PTP を経験した結果，PTPは，1）門脈の血行動態を 明確に把握し得るため，手術々式の決定に重要である。

2）手術を安全で確実に施行しらる．3）街後の血行部 清の成否を確認しらる，4）脾堅短絡路のある症例を释 験し, 術後の肝性脳症の発症をX線上で推測した。

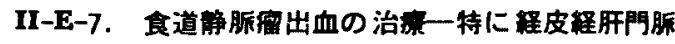
造坛を用いた静脈瘦塞栓術（PTO）

紀南総合病院外科

$$
\begin{aligned}
& \text { 传谷 稔, 汁本 雅一，大江 宏一 } \\
& \text { 田村 謙二, 大谷 正勝, 平中 俊行 } \\
& \text { 北川陽一郎，金香 光範 } \\
& \text { 同 心血管外科 大西 健二, 森崎 弘士 }
\end{aligned}
$$

食道静脈瘤出血に際し，保存的療法により止血し待期 手術にもっていく様努力する事は本症の治潦成續の向上 に大切な事である. 5 症例に1974年 Lunderquist が報告 した経皮経肝門脈造影を用いての静脈瘤塞栓術を行い 4 症例に手術を行い得た。

手技は，(1) $21 \mathrm{G}$ 穿刺針，(2) ベニューラ静脈留直針

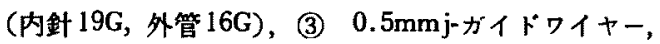

(4) $0.9 \mathrm{mmj}$-ガイドワイヤー, (5) $7 \mathrm{~F}$ 腹垫動脈造影用 カテーテルより成るセットを用意しており，最初は21G の細い、穿刺針を用いて肝内門脈末梢枝を穿刺するので比 較的安全に施行し得る。塞栓物質としては $50 \%$ Glucose 30〜50ml，及び，トロンビン300〜500単位を引続き注入 する.PTO 施行前後の状態, 変化を全庭例に於いて比 較してみると，臨床的には Child の Classification に隼 じてみると 2 例にBからAへの改善がみられた. 出血量 は3例に隇少或いは殆んど完全な止血を諗めた。内視鏡 的には，門脈外科研究会内視鏡判定規準上, Grade $\mathbb{I I} \rightarrow$ II 1 例, Grade IV $\rightarrow$ III， II 各 I 例と著明な改善が認め5 れた。

PTO は手技，止血期間，塞栓物質，合併症等に関し て未だ改良点或いは未解決の問題をかかえてはいるか， 食道静脈瘤出血に対する保存的療法の1つとして一般状 態を改善させ，手術の施行を可能にする有用な方法であ ると考えられる。

座長のまとめ 小林 迪夫

担当した 7 題は脾疾患における摘脾の適応阔する問 題, ならびに門脈生宇進症に対する释皮経肝門脈造影及 
びそれを用いての食道静脈㢚塞栓療法についての報告で あった。

愛媛大第 1 外科後藤氏は遊走脾之脾仮性意腫を合併し た症例に摘脾を行って治窈せしぬた 1 例を報告された か、、本症例は脾の支持靱带を欠除した先天性遊走脾と考 えられ，興味ある应例であった。

つぎに, 田中 (東京女子医大消化器病センター外科), 岩永（国立浜田病院外科）の両氏は胆石症を合併した溶 血性黄疾例に摘脾と胆雚摘除を併施した释験を報告され たが，とくに岩永の1例は術中はじめて胆石症の合併を 確認されたもので, 溶血性黄㡺では30〜 40\%の高頻度に 胆石症を合併することを念頭において，たと文術前胆石 が発見されなくとも，術中かならす胆重を精査し，必要 あれば同時に胆摘を併施すべことを強調され，会員の 翼同を得られた。

つついて高橋氏（岩手椙立中央病院外科）は溶血性黄 㡺，ITP，白血病，Felty 症候群，外傷なとに対する摘 脾の適応を論ぜられたか，とくに，ITPにおけるステ ロイド療法と手術時期，摘脾効果の予測について質疑あ ク，その判別として，ステロイド有効例が摘脾効果むす くれていることが坐長より追加された。

つぎに予定された脾出血に対する $\mathrm{CO}_{2}$ レーザーの止 血効果についての発表は中止されたが，上腹部手術のさ いに時にみられる脾損傷に対する対策として興味ある演 題であると考えられたので、ここに記録に留めておく。

佐藤氏（成田日赤病院外科）は経皮経所門脈造影法 (PTP) を直達手術の術前後に行い, 手術の効果を評価 する試みを報告されたか，確かに PTP は食道静脈溜の 外科治療にさいし，最も必要な頭側副血行路の状態を知 り, さらに手術效果を判定する上に極めて有用なるのと 考えられ，各施設でとりあげられる気運にある.ささらに 多数症例についても本法を用いて検討を加え，各術式の 選択，評価が 1 歩前進することを期待したい，

最後に佐谷（紀南綜合病院外科）はこの PTP の手技 を用いての静脈塞栓術を救急出血例 5 例に施行，4例に 成功したと報告されたか;，Lunderquist，Viamonte の報 告にああるよらに，造隔時に打ける再開通の危惧は否定 できす，時期をみて手術を行らべきたとの発言もあり， 本法の食道静脈瘤治療に占める意義についてはなお検討 の必要があると考えられた。

以上，各演題とも多数の質疑，追加がなされたが，詳 細は省略させていただき，座長がその意をくんで総括さ せていたたいた。
門脈 II (E-8～15) 座長 武田 仁良

\section{II-E-8. 食道竫脈㾇合併肝案の手術経駼}

東京女子医科大学消化器病センター

高橋 健, 小林誠一郎, 鉿木 茂 木下 裙宏, 武藤 晴臣, 原田 瑞也

橋本 忠美, 山名 泰夫, 長岡 数

近年の診断技術の進歩に伴い，肝癌が発見される機会 が增してきているが，我が国の肝癌应例の多くが肝硬変 を基盤としているため，肝切除術の適応の有無と同時に 食道静脈瘤を合併している例に対する対処す大きな問題 となっている.肝切除術後更に門脈王の元進が予想され るため静脈瘤破裂の危険性も增するのと考えられるた め，同時に何らかの対処が必要となる.我々は最近この よらな症例を 4 例绎験し，2 例に対しては食道離断術を 附加し， 2 例に対しては遠位脾肾静脈吻合術を附加手術 として行なっている４例ともに一応経過は順調に退院 している．食道離断を行なった 2 例は 1 例は吐血の既応。 がある例であり右葉区域の肝癌で術前 ICG $\mathrm{R}_{15}$ は14\% であった，阶切除は右葉後区域部分切除を行なった。 術後 ICG $\mathbf{R}_{15}$ は26\%であった。静脈瘤は消失していた が，肝癌の断端再発により半年後に死亡した。すう1例 は両葉に肝癌を認め左葉外側区域切除之右葉肝癌核出術 を行ったるのであり術前 ICG $\mathrm{R}_{15} 19 \%$ であったが術後 $36 \%$ てった．遠位脾腎静脈吻合の 2 例は之もに右葉肝 癌であり，1例は吐血の既応がある。この例は ICG 30 \%であるため右葉前区域のみを行い術後 ICG $57 \%$ とな り腹水, 黄疸が持綄したが 3 力を要して退院し 1 年 6 カ月現在健在である.他の1例は ICG 14\%であるため 右葉切除を施行している、未だ 4 例の経験であり，いず れの術式が良いか云々できないか，いずれにしろ静脈瘤 に対する対処を附加してもたいした手衍侵襲の附加には ならない，残存肝機能を我々の開発した区域肝機能検査 法により推測し切除許容範团を決定し，何らかの静脈瘤 の手術を附加している.

\section{II-E-9. 食道静脈粱患者における術前術後の血小板} の推移

愛媛大学第 2 外科

永井熟, 石戸谷 武, 大湏賀 洋
稲生 章, 井上 博人, 木村 茂

目的：食道静脈瘤にて直達手術を行なった患者は，い ずれる血小板数の著明な减少がみられ，術中術後血小板 輸血を施行することが多かった。そこで，術前術後の血 小板数の推移を調へ，血小板数堿少の成因について検討 
を加えた。

対象ならびに成䋶：最近 2 年間に20例の食道静脈瘟直 達手術を行なった。祭急手術 8 例，待期手術 8 例，予防 手術 4 例であった。手葕方法別に分けると，A群：経胸 的食道離断の及，7例. B 群：食道離断後二期的摘脾兼 上部胃血行郭清， 5 例. C群 : 上記腹部手術後二期的食 道離断， 3 例. $\mathrm{D}$ 群: 一期的胸部腹部手術，4例。 E 群：摘脾兼上部胃血行郭清のみ，1例.であった。これ ら症例の各手術操作ごとの血小板数の術前術後の推移を みると，食道離断後血小板数は，軽度であるが增加を示 した ( $\mathrm{ABC}$ 群)。しかし肝機能排泄試験 ICG 血漿消失 率K值が低いものは，增加傾向が悪かった，摘脾後血小 板数は，術後 7〜14日で正常值又はそれ以上の增加を示 乙，その後正常值に回復するるのが多かったが，ICG $\mathbf{k}$ 值の低いわのは，增加傾向が悪く，正常值に回復しな い症例むあった (BCDE 群).

結論：食道静脈㴔患者においては，いずれる血小板数 の減少がられ，その原因は，主に脾機能九進である が, 静脈痹に和ける血小板の消費・破壊, 肝機能障害に よる血小板の骨蹎に拾ける産生不良もその成因の1つと 推測される。

II-E-10. 門脈圧え進症における 脾摘後血小板增多と 血栓症

東京大学第 2 外科

上笹 功, 二川 俊二, 比田井 耕

杉浦 光雄, 和田 達雄

同中央検查部 山中学

都立府中病院 二之宮景光

門脈王六進症やある種の血液疾患における脾摘除術後 の血小板增多に関連して，血栓症合併の危険が従来より 指摘されている。我々も，門脈圧六進症の脾摘除術後に 血栓症を合併した例を経験し，その一因として血液凝固 能六進が推察された．今回，脾機能六進を呈し脾摘除術 を受けた門脈圧穴進症28例について血小板数，血小板凝 集能,トロンボェラストグラム等の変動を謂ぺた。

肝硬変症11例，特発性門脈圧六進症 8 例について脾摘 後の血小板数の変動をみると，術後次第に增加の㑯向が 認められ，2 週目には最高值に達した。 その後は渐減す るが 4 週目でる増加は維持されていた。 また特発性門脈 圧六進症の方がその增加は著明であった。

次に肝硬変症10例, 特発性門脈圧元進症 6 例の血小板 凝集能の変動をみた、コラゲンあるいは ADP 添加によ り最大凝集率を算定する方法に従った。両疾患とるに術
後 1 週目，2 週目には術前と比較し有意に疑集能九進を 認め，4週でも六進の傾向がられた。さらに血液凝固 過程をトロンボェラストグラムにて観察したところ，脾 摘除術後における $\mathrm{K}, \mathrm{Ma}$ 値の短縮ないし增大が目立 ち，凝固能穴進状態を呈していた。

以上の検討上り，門脈圧充進症に招いて脾摘除術後保 は血小板数の增加のみならず, その機能立進も徙めら れ，凝固六進状態にあると推察された。従って凝血学的 にも血柱症合併の危険を有すると考えられ，術後管理 上，その予防には充分な配虑が必要である。

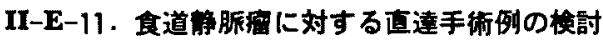
北里大学外科

$$
\begin{aligned}
& \text { ○根本 谱, 吉田 宗紀, 島津 盛一 } \\
& \text { 鑘水 民生, 大島 行彦, 佐藤 光史 } \\
& \text { 大宮 東生, 内田 久則, 大場 正己 } \\
& \text { 阿曾 弘一 }
\end{aligned}
$$

同放射線科 草野 正一

食道静脈㿎に対して当科では直達手術を標準術式とし て施行してきた．肝硬变37例，特発性門脈圧六進症 13 例，肝前性門脈閉塞 4 例計54例で，その $80 \%$ は開胸・開 腹による中下部食道・胃噴門部の血行遮断を伴ういわゆ る東大第 2 外科法て，経腹的食道器械離断は 1 例, Hassab 手術10例である. 手術死は緊急手術 6 例中 2 例が肝 不全之膿胸で，待期手術21例中 1 例か：朖胸で死亡した か，予防的手術16例には手術死はない，後期死は祭急手 術 6 例中 3 例之待期手術中の 3 例が肝不全で，また待期 手㫱の 1 例と予防的手術の 2 例が肝癌で死亡した。緊急 手術例はすべて Child 分類 C群で待期手術例ですC群 の成績が不良であった。経胸的食道離断術では90\%に竞 脈瘤の消失がみられ術後破裂例はない，Hassab 手術で は静脈瘤が胃に限局していた症例はすべて消失したが， 下部食道にもみられた症例では消失 $40 \%$ ，改善 $40 \%$ ，再 破裂 1 例 $20 \%$ でった。昭和52年以降は緊急吐血例飞㤌 バソプレッシンの上腸間膜動脈持続動注法で，最近は PTPE により可及的に止血させ待期手術とするようにし てから成績の向上をみた。IPHと肝前性閏脈閉塞の生存 率は100\%であるが，肝硬变では65\%で，また東大第 2 外科法に上る経胸的食道離断術の㛑急・待期・予防的手 術の遠隔生存率は夫々 $17 \cdot 76 \cdot 88 \%$ 平均 $72 \%$ で，この5 ちの $94 \%$ は社会復帰している. 所で PTPEで止血でき ても約 1 力月後肝不全で死亡した 3 例を経耠して扰り， このよらな症例を手術非適応と鑑別できるのもPTPE の効用の一つと考えている。 


\section{II-E-12. 经腋的食道粘䑏離断術街後の食道機能}

千葉大学第 2 外科

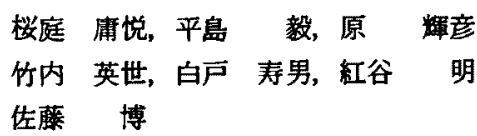

教室では，従来より各種食道疾患に対し，その病態生 理を知るため, 術前術後において食道内压測定を施行し ている. 今回は，食道静脈瘤に対し，教室で標準術式と する経腹的食道粘膜唯断術を施行した症例に，食道内压 娜定を行ない, 術前と比較検討し, 本症の食道運動機能 面における若千の知見を得たので報告する．なお内王検

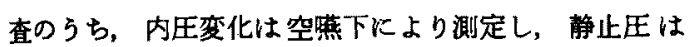
non-infusion method により測定した。

まず,内王変化は, 術後44例に施行し, 出現した陽性 波を発現時間，持続時間，波高の 3 点につき術前59例と 比較した，発現時間では，術後は下部食道において平均 4.86秒と術前5.22秒よりややはやくなったが，上部，中 部, 接合部では,それぞれ2.06秒，4.02秒，6.59秒と術 前と同じく，上部食道から接合部への伝達性は維持され ていた，持続時間では，接合部において，術後やや延長 したが，手術操作の影響と考えられた，波高では，各部 位において衍前とほぼ同じ值を示し，静脈澞が軽減して るなお正常例の約半分であった。

次に静止王につき検討した，衍前の食道静止王曲線と 正常例を比較すると, 術前62例平均位正常例20例平均に くらへ，逆流防止機構である下部昇圧帯の最高圧の低下 と带長の延長がみられ，食道胃圧差が大きい，術後37例 平均と術前とをくらべると, 下部昇圧带の最高王は, 術 前7.58 $\mathrm{cmH}_{2} \mathrm{O}$ に対し， $6.45 \mathrm{cmH}_{2} \mathrm{O}$ を低下したが有意 差はなかった。带長は $4.04 \mathrm{~cm}$ と $3.99 \mathrm{~cm}$ で同じであっ た、すなから，下部昇王帯の機能は術後も同じであった と言える。食道胃圧差は術後 $9.27 \mathrm{cmH}_{2} \mathrm{O}$ と, 術前 10.65 $\mathrm{cmH}_{2} \mathrm{O}$ より小さくなり, 正常例 $6.97 \mathrm{cmH}_{2} \mathrm{O}$ に近づい t.

\section{II-E-13，食道觧脈瘦に対する直達手術の後㟟症} 九州大学第 2 外科 杉町 主蔵 他

食道静脈瘤に対する直達手術は現在な和種々の術式が 試みられており，いまだ統一した見解がえられていな い、我々は経胸・释横隔膜的経路による下部食道胃の血 行郭清と食道離断が肝に及ぼす影罯が少ないことをすで に報告してきたが，厷範血行郭清と食道麈断を行ら場合 K, Hiatus を温存することにより，術後の後遗症が少 ないことが判明した。現在までに本法を12例に施行し，
術後の食道内圧を測定したところ，下部昇王帯は正常に 保たれており，水負荷やテトラガストリン静注に対して むよく反応した。またこれまでの術式においてて時々み られていた逆流性食道炎や噴門無弛縓は本術式により防 止できるようになった，以上，我々が行っている啳遺症 防止のための食道崔断術について報告した。

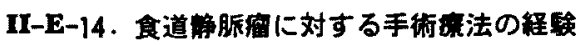

島根塄立中央病院外科

○小林真佐夫，倉塚 均，山口 孝之 尽科 彰夫，松川 东広，増田 和人

最近 5 年間に食道静脈㾿に対する手術を 25 症例に，延 べ27回の手術を施行した，男性15例，女性10例であり， 年龄は38歳から65歳までであった。旰硬変症の組織学的 分類は甲型肝硬変症 1 例, 乙型肝硬変症22例，肝線維症 2 例であった。

祭急手術は 2 例，手術回数は 3 回，待期手術は19例， 手術回数は20回, 予防的手術は 4 例である. 手術直接死 亡は㗨急手術に 1 例, 待期手術に 1 例, 遠隔死亡は 2 例 である.緊急手術 2 例中 1 例は胃横断術を施行したか， 衍後 2 年 6 カ月で食道静脈㨨よりの再出血をきたし，緊 急手術として Mesocaval “H” shuntを施行した。他の 1 例は経腹的胃上部切除術を施行したが，術後10日目に 肝不全で死亡した。

待期手術19例の術式の内訳は，経腹的胃上部切除術が 16例，经腹的食道離断術か: 2 例，経胸 - 经横隔膜的食道 離断術が 例である. 経腹的胃上部切除術の 2 例は術後 14日目及び術後 8 カ月で肝不全のため死亡した. 再出血 の1例は緊急手術で Mesocaval “H” shuntを施行し た.この症例は術後 9 カ月で吐血をみたか，胃潰湯から の出血で，保存的治療で経過観察中である。

予防的手術は 4 例で, 全例, 経腹的胃上部切除術を施 行した.

食道静脈瘵の直達手術が上腹部に既におこなかれてお゙ り，食道静脈瘫からの再出血例に 対する手術として， Mesocaval “H” shunt は止血効果は充分であり，手技 的にも容易であり，再出血例に対する祭急手術として試 みられるべき術式と考えられる。しかし，症例数る少な く，術後経過年数す短いので，更に経過観察を要する.

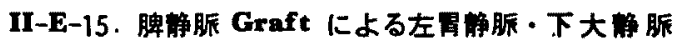
均合衒

抄録号参照 